\title{
Rozwiązywanie układów zbiorowych pracy - uwagi de lege lata i de lege ferenda
}

\section{Uwagi wstępne}

Crtykuł stanowi nawiązanie do rozważań profesora Wacława Szuberta, zamieszczonych w niezwykle cenionej monografii Układy zbiorowe pracy, która ukazała się nakładem Państwowego Wydawnictwa Naukowego w 1960 r. Profesor W. Szubert, powołując się na ustawodawstwo i piśmiennictwo okresu międzywojennego, poddaje pod rozwagę dopuszczalność rozwiązania układu zbiorowego pracy ze skutkiem natychmiastowym. Zdaniem autora prawo rozwiązania układu w tym nadzwyczajnym trybie może być analizowane w dwóch sytuacjach. Pierwsza odnosi się do zmian gospodarczych, które uniemożliwiają dalsze stosowanie układu. Drugi przykład wiąże się natomiast z poważnym naruszeniem postanowień układu przez jedną ze stron, jednakże w praktyce chodzi o stronę związkową ${ }^{1}$. W. Szubert podkreśla, że rozwiązanie natychmiastowe może obejmować wyłącznie sytuacje zmian bardzo zasadniczych, nie dających się przewidzieć, które narażają jedną ze stron $\mathrm{w}$ razie dalszego obowiązywania układu na straty „W stopniu sprzecznym z poczuciem słuszności". Również drugi przykład może dotyczyć wyłącznie bardzo istotnych uchybień jednej ze stron, w których inne formy reakcji drugiej strony byłyby niewystarczające².

Należy jednak zauważyć, że W. Szubert prowadził swój wywód na podstawie stanu prawnego sprzed obowiązywania działu jedenastego kodeksu pracy. Autor powoływał się na regulację okresu międzywojennego, a w szczególności ustawę z dnia 14 kwietnia 1937 r. o układach zbiorowych pracy ${ }^{3}$. Na mocy art. 20 tej ustawy, w stosunku do układu

* Dr, Katedra Prawa Pracy, Wydział Prawa i Administracji Uniwersytetu Kard. Stefana Wyszyńskiego w Warszawie.

1 Por. W. Szubert, Układy zbiorowe pracy, Warszawa 1960, s. 294.

2 Ibidem, s. 294-295.

${ }^{3}$ DzU, 1937, nr 31, poz. 242. 
zbiorowego pracy zawartego na czas oznaczony, rozjemca mógł na wniosek jednego z zainteresowanych, po wysłuchaniu uczestnika układu, orzec zwolnienie go od uczestnictwa w układzie przed upływem jego terminu, jeżeli według zasad dobrej wiary i po rozważeniu interesów stron uznał to za niezbędne. Rozjemca mógł podjąć decyzję, jeżeli zaistniał jeden $\mathrm{z}$ dwóch powodów:

1) nastąpiło wyraźne uchybienie postanowieniom układu przez któregokolwiek z jego uczestników, stanowiących stronę przeciwną,

2) doszło do znacznej zmiany ogólnych warunków gospodarczych od czasu zawarcia układu, czego strony nie mogły przewidzieć.

Natychmiastowe rozwiązanie układu zbiorowego pracy nie było zatem prawem strony, lecz leżało w gestii rozjemcy, który podejmował decyzję z uwzględnieniem interesu obu stron układu. Ponadto „zwolnienie od uczestnictwa w układzie" obejmowało wyłącznie układy zawarte na czas oznaczony.

\section{Rozwiązanie układu zbiorowego pracy w kontekście art. 241 kodeksu pracy}

Sposoby ustania układów zbiorowych pracy zostały wskazane $\mathrm{w}$ art. $241^{7}$ k.p., który przewiduje, że układ rozwiązuje się

1) na podstawie zgodnego oświadczenia stron,

2) z upływem okresu, na który został zawarty,

3) z upływem okresu wypowiedzenia dokonanego przez jedną ze stron.

Autorzy komentarzy do kodeksu pracy zgodnie przyjmują że wyliczenie ma charakter enumeratywny, a w konsekwencji jednostronne rozwiązanie układu zbiorowego $\mathrm{w}$ trybie natychmiastowym jest niedopuszczalne ${ }^{4}$. G. Goździewicz zastrzega, nawiązując zapewne do tradycji układowej okresu międzywojennego, iż żadne okoliczności, bez względu na to, czy polegają na zmianie ogólnych warunków ekonomicznych, czy też na oczywistym uchybieniu któregokolwiek z partnerów układu, nie uzasadniają zerwania układu w tym trybie ${ }^{5}$. W zasadzie autorzy nie przytaczają dokładniej powodów takiej interpretacji. Nie komentują także ratio legis omawianej regulacji.

${ }^{4}$ Por. m.in.: G. Goździewicz w: Kodeks pracy. Komentarz, red. W. Muszalski, Warszawa 2011, s. 1111; J. Piątkowski w: Kodeks pracy. Komentarz, red. K.W. Baran, Warszawa 2014, s. 1310; K. Rączka w: M. Gersdorf, K. Rączka, M. Raczkowski, Kodeks pracy. Komentarz, Warszawa 2011, s. 1015; I. Sierocka, Rozwiazanie układu zbiorowego pracy, [w:] Układy zbiorowe pracy. W stulecie urodzin Profesora Wactawa Szuberta, red. Z. Góral, Warszawa 2013, s. 369 i J. Stelina, Kodeks pracy. Komentarz, red. U. Jackowiak, LEX, Gdańsk 2004.

${ }^{5}$ G. Goździewicz w: Kodeks pracy. Komentarz..., s. 1111. 
Podobną ścisłą wykładnię art. $241^{7}$ k.p. prezentuje Sąd Najwyższy, który w wyroku z dnia 11 marca 2014 r., III PK 78/13, wypowiedział pogląd, że strony układu zbiorowego pracy nie mogą wprowadzać do jego treści postanowień ograniczających możliwość rozwiązywania układu z uwagi na bezwzględnie wiążący charakter normy z art. $241^{7} \S 1$ k.p. ${ }^{6}$ Orzeczenie to, co do swej istoty, polegało na ograniczeniu możliwości stosowania tzw. klauzul wieczności w układach zbiorowych pracy, które dotąd były przez judykaturę dopuszczalne jako element swobody negocjacyjnej stron układu zbiorowego pracy. Zdaniem Sądu Najwyższego, zmiana kodeksu pracy dokonana ustawą z 29 września 1994 r. o zmianie ustawy Kodeks pracy oraz o zmianie niektórych ustaw ${ }^{7}$, wprowadziła z dniem 26 listopada 1994 r. istotną modyfikację treści działu XI kodeksu pracy zatytułowanego Układy Zbiorowe Pracy, zamieszczając w nim m.in. art. $2417 \S 1$ k.p. o treści obowiązującej do chwili obecnej, określający w sposób wyczerpujący sposoby rozwiązania układu zbiorowego: na podstawie zgodnego oświadczenia stron, z upływem okresu, na jaki został zawarty oraz $\mathrm{z}$ upływem okresu wypowiedzenia dokonanego przez jedną ze stron. Co istotne, sąd ten wyraził pogląd, że norma art. $241^{7} \S 1$ k.p. ma charakter ustrojowy, a nie obligacyjny, co oznacza, że mamy do czynienia z przepisem bezwzględnie obowiązującym (ius cogens).

W odniesieniu do klauzuli wieczności sąd stoi na stanowisku, że wprowadzanie do treści układu zbiorowego postanowień ograniczających możliwość jego rozwiązania, choćby poprzez uzależnienie jego skuteczności od pozytywnej opinii drugiej strony, nie zostało przewidziane w treści art. 240 k.p., określającego przedmiot regulacji układowej z podziałem na część normatywną i obligacyjną ani w art. 2411 k.p., zawierającym wyszczególnienie postanowień o charakterze obligacyjnym, określających wzajemne zobowiązania stron układu przy jego stosowaniu, podlegających regulacji układowej. Przywołane stanowisko prowadzi zatem do wniosku, że w ocenie Sądu Najwyższego nie będzie również dopuszczalne wprowadzenie do układu prawa natychmiastowego rozwiązania układu przez jedną ze stron, nawet w przypadkach ściśle wskazanych w układzie, czy też prawa odstąpienia od układu. Tym samym sąd ten, powołując się na zasadę wolności układowej, w istocie ją ograniczył, nie dając stronom żadnej możliwości modyfikowania czasu obowiązywania układu - nie tylko w sensie jego przymusowego dalszego obowiązywania (do czasu zawarcia nowego układu), lecz również natychmiastowego rozwiązania układu przez jedną ze stron w sytuacjach nadzwyczajnych.

${ }^{6}$ LEX nr 1480282, „Gazeta Prawna. Kadry i Płace” 2014, nr 132, s. 8.

7 DzU, 1994, nr 113, poz. 547. 
Sąd zwraca uwagę, że wyrazem zasady wolności układowej jest z jednej strony uprawnienie związków zawodowych oraz pracodawców i ich związków do zawierania układów zbiorowych pracy, stanowiących autonomiczne źródła prawa pracy w rozumieniu art. $9 \S 1$ k.p., a z drugiej strony dopuszczalność rozwiązania układu m.in. w drodze jednostronnego wypowiedzenia układu zbiorowego pracy przez każdą ze stron tego układu, przewidziana w art. $2417 \S 1$ pkt 3 k.p. I w tym miejscu wolność układowa $\mathrm{w}$ rozumieniu judykatury kończy się. Strony mogą bowiem korzystać z wolności rozwiązywania układu zbiorowego pracy jedynie $\mathrm{w}$ takim zakresie, jaki wprost wynika $\mathrm{z}$ art. $241^{7} \S 1$ k.p. W konsekwencji Sąd Najwyższy zakazuje jakichkolwiek odstępstw od treści analizowanego przepisu, także w sytuacji odwrotnej od tej, która polega na konieczności dalszego obowiązywania układu, mimo jego wypowiedzenia. Łatwo wyobrazić sobie przypadek, o którym mowa była we wcześniejszych rozważaniach, kiedy jedna ze stron nie jest w stanie dalej stosować układu z uwagi na wcześniej nieprzewidziane okoliczności (np. istotne pogorszenie sytuacji ekonomicznej lub rażące naruszenie postanowień układowych przez jedną ze stron). Nawet w takiej sytuacji, mając na uwadze stanowisko Sądu Najwyższego, możliwe będzie jedynie rozwiązanie układu za wypowiedzeniem lub zgodą drugiej strony na jego rozwiązanie natychmiastowe, czyli za porozumieniem stron.

Stanowisko dotyczące bezwzględnie wiążącego charakteru przepisów art. $241^{7} \S 1$ k.p. może budzić wątpliwości także z punktu widzenia jego wykładni. Przepis ten daje stronom układu prawo uzgodnienia innego okresu wypowiedzenia niż wskazany w art. $241^{7} \S 3$ k.p., który wynosi trzy miesiące kalendarzowe. Strony, na mocy wskazanego przepisu, mogą ustalić dowolny okres wypowiedzenia, a zatem skrócić go maksymalnie, nawet do kilku dni. $W$ istocie więc strony układu mogą pośrednio de facto doprowadzić do natychmiastowego rozwiązania układu, przy zastosowaniu bardzo krótkiego okresu wypowiedzenia. Wydaje sie ponadto, że nie ma przeszkód, aby strony układu dodały obowiązek podawania przyczyny w celu zastosowania tego krótkiego trybu wypowiedzenia, czego prawo im nie zabrania. Wprawdzie wypowiedzenie układu, jak przyjmuje się $\mathrm{w}$ piśmiennictwie prawniczym i judykaturze, ma charakter abstrakcyjny ${ }^{8}$, a nie kauzalny, jednak nie można stronom odmówić prawa wprowadzenia obowiązku podawania przyczyny w razie zaistnienia nadzwyczajnych okoliczności, o których mowa powyżej.

${ }^{8}$ Por. cytowany wyrok Sądu Najwyższego z 11 marca 2014 r., III PK 78/13; J. Piątkowski w: Kodeks pracy. Komentarz..., s. 1310; J. Stelina, Kodeks pracy. Komentarz... 


\section{Charakter prawny układu a tryb jego rozwiązania}

W cytowanym wcześniej wyroku z 11 marca 2014 r. Sąd Najwyższy stara się nie dostrzegać, że zgodnie z art. $240 \S 1$ k.p. układ zbiorowy pracy składa się z tzw. części normatywnej oraz obligacyjnej. W doktrynie wyróżnia się ponadto tzw. trzecią część układu, której zakres regulacji nie daje sie zakwalifikować do dwóch pierwszych. Zgodnie z art. $240 \S 1$ pkt. 2 k.p. układ określa wzajemne zobowiązania stron układu, w tym dotyczące stosowania układu i przestrzegania jego postanowień. W uchwale z 4 stycznia 2008 r., I PZP 9/07 Sąd Najwyższy uznał, że obligacyjny charakter mają regulacje dotyczące „stosowania układu i przestrzegania jego postanowien", a więc także postanowienia dotyczące dalszego stosowania (obowiązywania) układu po jego rozwiązaniu w wyniku wypowiedzenia. Abstrahując od konsekwencji prawnych cytowanej wykładni, głównie w jego wymiarze praktycznym (dopuszczalność stosowania klauzul wieczności przez strony układu jako przejaw ich woli), należy zwrócić uwagę, że uprzednio judykatura stała na stanowisku wolności układowej, której przejawem w kodeksie pracy było istnienie części obligacyjnej układu. W późniejszym wyroku z 2014 r. Sąd Najwyższy przyznał stronom układu wolność układową wyłącznie w ramach kompetencji ustawowej, wynikającej z kodeksu pracy.

Sąd Najwyższy, dokonując prawnej oceny tzw. klauzul wieczności, przeprowadził swoje rozważania w sposób prowadzący do istotnego osłabienia idei wolności rokowań zbiorowych, która jest fundamentalną zasadą zbiorowego prawa pracy. Należy podkreślić, że art. 59 ust. 2 konstytucji nadaje wolności rokowań inny sens niż wynikający z uprzednio obowiązującego stanu prawnego. Konstytucyjna zasada wolności rokowań zbiorowych daje partnerom społecznym większą niezależność od ustawodawcy państwowego i wzmacnia ich autonomię w zakresie tworzenia norm prawa pracy w drodze rokowań zbiorowych. Pogląd ten znajduje oparcie w treści art. 20 ustawy zasadniczej, zgodnie z którym społeczna gospodarka rynkowa, oparta na wolności działalności gospodarczej, własności prywatnej oraz solidarności, dialogu i współpracy partnerów społecznych stanowi podstawę ustroju gospodarczego Rzeczypospolitej Polskiej. W kontekście obu regulacji konstytucyjnych zasadnie można przyjmować, że układy zbiorowe pracy nie wymagają tak daleko posuniętego nadzoru państwowego, a dialog i współpraca partnerów społecznych musi opierać się na większym do nich zaufaniu ze strony państwa. Oczywiste jest, że z uwagi na normatywny charakter układu zbiorowego pracy wymaga on wprowadzenia reguł przez ustawodawcę państwowego ${ }^{9}$, jednak nie powinny one wkraczać zbyt daleko, ponieważ zagraża to wolności układowej.

${ }^{9}$ Por. G. Goździewicz, Szczególne właściwości norm prawa pracy, Toruń 1989, s. 203. 
W tym miejscu należy przypomnieć, że układ zbiorowy pracy ma charakter nie tylko normatywny, ale także umowny. Zgodnie z opinią A. Nikischa według wcześniejszych i powojennych teorii układ zbiorowy pracy jest umową prawa prywatnego, jednak w jej normatywnej części jest dwustronnym, korporacyjnym, wiążącym układem normotwórczym, a w części obligacyjnej wzajemnym porozumieniem o charakterze ciągłym, które podlega jednolitym warunkom prawnym ${ }^{10}$. Z uwagi na normotwórczy charakter układów zbiorowych pracy nadzór ustawodawcy jest konieczny. Jak podkreśla się w literaturze, właściwe jest, że państwo określa, komu przyznać autonomię, w jakiej formie i w jakim zakresie przedmiotowym strony układu są uprawnione do działania i w stosunku do kogo moga obowiązywać uzgodnione przez nie normy. W literaturze powszechnie akceptuje się dualną naturę prawną układu zbiorowego pracy, w której łączą się funkcje prawnie wiążącego układu normotwórczego z umową prawa cywilnego. Trudno jednoznacznie przesądzić, która cecha układu ma charakter dominujący. Jak zauważa A. Nikisch, nawet jeśli państwo daje parterom układowym do dyspozycji układ jako instrument do rozwijania ich autonomii, to nie wynika z tego w żadnym razie, że układ zbiorowy pracy może być uznany wyłącznie za umowę prawa prywatnego ${ }^{11}$. Zdaniem niektórych autorów element umowny układu wydaje sie nawet dominujący, biorąc pod uwagę okoliczności jego zawarcia, treść oraz czas obowiązywania, które są uzależnione od woli stron ${ }^{12}$. Jak podkreśla L. Florek, umowny charakter układu ma ścisły związek z wolnością układową. Jej wyrazem jest swoboda określenia przez strony rodzaju układu, jego zakresu podmiotowego, przedmiotu, a także rozstrzygania sporów związanych z zawarciem układu ${ }^{13}$. Listę tę należałoby uzupełnić poprzez dodanie prawa rozwiązania układu zgodnie z wolą stron. Zakres tej swobody byłby niewątpliwie szerszy, gdyby nie treść art. $241^{7}$ k.p., który bez względu na przyjęty sposób wykładni zawsze ogranicza autonomię stron w tym zakresie.

Należy tu zwrócić uwagę na fakt, że już od początku prawnego uregulowania układów zbiorowych pracy polski ustawodawca przyjął model nadzoru państwowego, który w szczególności obejmuje kwestię zakończenia bytu prawnego układu. Prawo rozwiązywania układu wynika wprost z przepisów prawa, najpierw z art. 19 i 20 ustawy z 1937 r. o układach zbiorowych pracy, a obecnie $\mathrm{z}$ art. $241^{7}$ k.p. Takiej kontroli pań-

${ }^{10}$ Por. A. Nikisch, Arbeitsrecht, zweiter Band: Koalitionsrecht, Arbeitskampfrecht und Tarifvertragsrecht, Tübingen 1959, s. 216.

11 Ibidem, s. 217.

12 Por. L. Florek, Charakter prawny układu zbiorowego pracy, [w:] Układy zbiorowe w demokratycznym ustroju pracy. Studium z zakresu prawa pracy, red. J. Wratny, Warszawa 1997, s. 37.

${ }^{13}$ Ibidem, s. 38. 
stwowej nie wprowadzono w ustawodawstwie niemieckim, gdzie do rozwiązania układu stosuje się ogólne reguły prawa zobowiązań, dotyczące umów wzajemnych. W praktyce układowej strony mogą przewidywać zarówno różne sposoby ustania układu, jak też tryby jego rozwiązania. I tak dopuszcza się stosowanie układów terminowych, warunkowych, uchylających, a także rozwiązanie za wypowiedzeniem i bez wypowiedzenia. Wypowiedzenie układu zawartego na określony czas jest dopuszczalne wyłącznie wówczas, gdy strony taką możliwość wyraźnie przewidziały w układzie ${ }^{14}$.

W tamtejszym ustawodawstwie podstawę prawną rozwiązania układu zbiorowego pracy $\mathrm{w}$ trybie natychmiastowym może stanowić ustawa. Na mocy § 314 (1) BGB każda ze stron ma prawo rozwiązać umowę bez okresu wypowiedzenia $z$ ważnych powodów. Takim ważnym powodem jest sytuacja, kiedy biorąc pod uwagę wszystkie okoliczności danego przypadku i rozważając interes obu stron, nie można oczekiwać dalszego obowiązywania umowy do upływu umówionego terminu jej trwania lub upływu terminu wypowiedzenia. Judykatura stosuje w tym przypadku zasadę ultima ratio. Jako przykłady sytuacji nadzwyczajnych, uprawniających do natychmiastowego rozwiązania układu przyjmuje się m.in.: ciężkie naruszenie obowiązków przez jedną ze stron, a w szczególności złamanie zasady pokoju społecznego, zmianę położenia prawnego lub utratę zdolności układowej. Rozwiązanie układu w tym trybie może nastąpić tylko wówczas, kiedy nie ma innej, mniej dolegliwej możliwości usunięcia tej sytuacji ${ }^{15}$. Należy pamiętać, że układ zbiorowy pracy jest układem normotwórczym regulującym warunki umowy osób trzecich i dlatego wymagane jest zaistnienie szczególnych powodów uprawniających strony do rozwiązania umowy w trybie natychmiastowym ${ }^{16}$.

\section{Wnioski}

Praktyka układowa w naszym kraju nie jest szczególnie rozpowszechniona i doceniana przez partnerów społecznych. Podczas gdy szacuje się, że w Niemczech w 2010 r. obowiązywało około 74000 układów zbiorowych pracy ${ }^{17}, \mathrm{w}$ Polsce było ich tylko kilka tysięcy. Powodów takiego staniu rzeczy zapewne jest kilka. Biorąc jednak pod uwage rozważania zawarte w niniejszym artykule, niewątpliwie jednym $z$ nich może być obawa

14 Por. M. Fanzen w: Erfurter Kommentar zum Arbeitsrecht, München 2012, s. 2637.

15 Por. M. Gładoch w: Kodeks pracy. Komentarz, red. A. Sobczyk, Warszawa 2014, s. 799.

16 Por. W. Hromadka, F. Maschmann, Arbeitsrecht Band 2: Kollektivarbeitsrecht + Arbeitsstreitigkeiten, Berlin-Heidelberg-New York 2008, s. 66.

17 Por. M. Fanzen w: Erfurter Kommentar zum Arbeitsrecht..., s. 2631. 
przed koniecznością stosowania układu zbiorowego pracy nawet wbrew woli jednej ze stron. Taka sytuacja może wystąpić w razie zawarcia tzw. klauzul wieczności, kiedy układ zbiorowy pracy, mimo jego wypowiedzenia, obowiązuje w dalszym ciągu, aż do zawarcia nowego układu. Innym problemem może być obowiązek stosowania układu nawet w przypadku bardzo złej sytuacji gospodarczej zakładu pracy, będącej konsekwencją zapaści ekonomicznej firm danej branży ${ }^{18}$. Rozwiązanie natychmiastowe układu jest możliwe wyłącznie za zgodą obu stron, co dla pracodawców niesie ryzyko, że do takiego porozumienia nigdy nie dojdzie. Wiele można by pisać o konieczności odpowiedzialności partnerów społecznych, jednak $\mathrm{w}$ praktyce spojrzenie na potrzeby przedsiębiorstwa bywa różne po stronie pracodawcy i po stronie związkowej.

Układ zbiorowy pracy jest szczególnym rodzajem porozumienia normatywnego, które kształtuje warunki pracy i płacy w indywidualnych umowach o pracę. Już chociażby z tego powodu układ taki wymaga nadzoru państwowego. Wydaje sie jednak, że obecna regulacja jest zbyt restrykcyjna, w szczególności gdy chodzi o tryby rozwiązania układu. Ustawodawca zdaje się nie dostrzegać szczególnych okoliczności, które mogą zaistnieć w praktyce funkcjonowania przedsiębiorstw. Odmiennie, w okresie dwudziestolecia międzywojennego widziano potrzebę natychmiastowego ustania układu $\mathrm{w}$ razie sytuacji nadzwyczajnych, których strony nie mogły przewidzieć przy zawieraniu układu zbiorowego pracy. W ustawie z 1937 r. rozjemca na wniosek partnera układowego miał prawo rozwiązać układ, kiedy jedna ze stron rażąco naruszała jego postanowienia lub też nastąpiło drastyczne pogorszenie sytuacji ekonomicznej przedsiębiorstw. Warta rozważenia jest także druga przesłanka, która związana jest z zaufaniem stron do siebie. Jeżeli związki zawodowe naruszyłyby klauzulę pokoju społecznego zawartą w układzie lub przystąpiły do sporu zbiorowego wbrew obowiązkowi wcześniejszego wypowiedzenia układu, wydaje się słuszne, aby pracodawca miał możliwość natychmiastowego rozwiązania układu. W tym przypadku należy bowiem wrócić do ogólnej zasady rokowań nad układem zbiorowym, opartych na zasadzie dobrej wiary stron.

\section{Bibliografia}

Fanzen M. w: Erfurter Kommentar zum Arbeitsrecht, München 2012.

Florek L., Charakter prawny układu zbiorowego pracy, [w:] Układy zbiorowe w demokratycznym ustroju pracy. Studium z zakresu prawa pracy, red. J. Wratny, Warszawa 1997.

Gładoch M. w: Kodeks pracy. Komentarz, red. A. Sobczyk, Warszawa 2014.

${ }^{18}$ Istotne pogorszenie się koniunktury obserwowane jest m.in. w branży górniczej. 
Goździewicz G., Szczególne właściwości norm prawa pracy, Toruń 1989.

Goździewicz G. w: Kodeks pracy. Komentarz, red. W. Muszalski, Warszawa 2011.

Hromadka W., Maschmann F., Arbeitsrecht Band 2: Kollektivarbeitsrecht, Arbeitsstreitigkeiten, Berlin-Heidelberg-New York 2008.

Nikisch A., Arbeitsrecht, zweiter Band: Koalitionsreht, Arbeitskampfrecht und Tarifoertragsrecht, Tübingen 1959.

Piątkowski J. w: Kodeks pracy. Komentarz, red. K.W. Baran, Warszawa 2014.

Rączka K. w: M. Gersdorf, K. Rączka, M. Raczkowski, Kodeks pracy. Komentarz, Warszawa 2011.

Sierocka I., Rozwiazanie układu zbiorowego pracy, [w:] Układy zbiorowe pracy. W stulecie urodzin Profesora Wacława Szuberta, red. Z. Góral, Warszawa 2013.

Stelina J., Kodeks pracy. Komentarz, red. U. Jackowiak, LEX, Gdańsk 2004.

Szubert W., Układy zbiorowe pracy, Warszawa 1960.

\section{Termination of Collective Labour Agreements - Remarks de lege lata and de lege ferenda}

\section{Summary}

The chapter refers to the opinions of Professor Wacław Schubert, presented in a monograph: Collective labour agreements. Professor W. Schubert analysed the possibility of immediate termination of the collective bargaining agreement. Is this procedure acceptable, as in German law? The author relied on the regulation of the interwar period, in particular the law dated 14 April 1937 on the collective agreements. It should be considered if an immediate termination of the collective agreement may be introduced to the Polish law. 